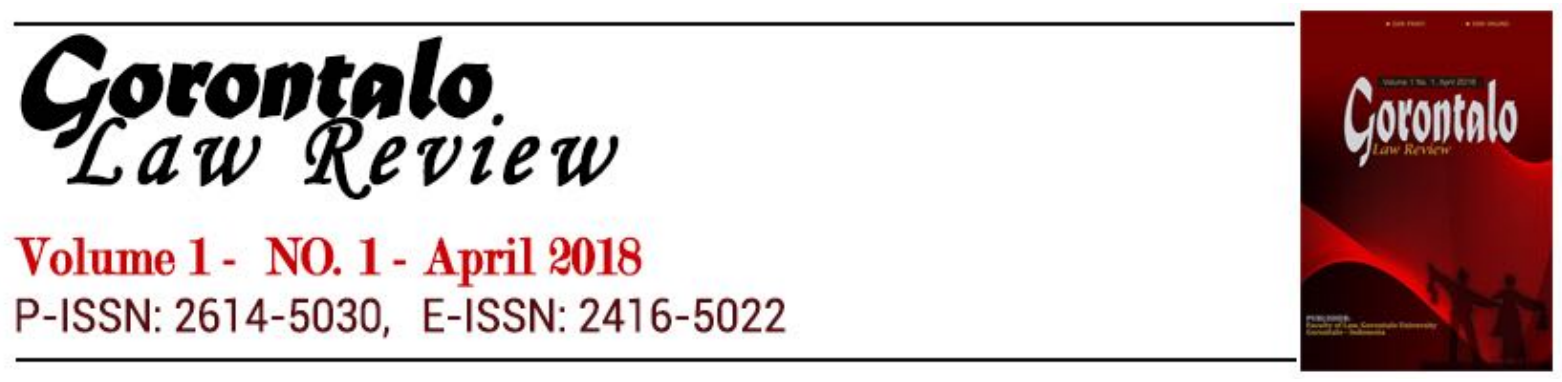

\title{
Kebijakan Pendidikan Anti Korupsi Di Perguruan Tinggi
}

\author{
Yusrianto Kadir \\ Ilmu Hukum, Fakultas Hukum, Universitas Gorontalo \\ Email: yusrikadir@gmail.com
}

\begin{abstract}
Reasoning various negative perceptions towards the direction of national education that has been considered not to characterize the national personality, especially about the output of education that tends not to reflect the values and principles of anti-corruption in work and daily, so that through formal education there should be an increase in terms of intensity. Simplistically, the formal education sector in Indonesia can play a role in meeting the need for corruption prevention. Preventive measures can indirectly pass through two approaches, first: targeting learners, and second: using the empowerment of learners to reduce the environment from permissive to corruption.

As for the problems in this paper is how the anti-corruption education policy in Higher Education and the extent of anti-corruption education policies in the prevention of corruption. With the aim to understand and analyze the role of anti-corruption education in growing the values and principles of anticorruption from an early age.

Through this anti-corruption education will be a provision for students to act honestly in the work. Of course, in order not to commit acts of corruption when later occupied a strategic position in an institution or served an important position in this bureaucracy. The facts show that highly educated people are vulnerable to the temptations of corruption because they usually occupy strategic positions in an institution or hold important positions in the bureaucracy.
\end{abstract}

Keywords: Policy, Anti-Corruption Education

\section{PENDAhUluan}

Pendidikan secara umum didefinisikan sebagai sebuah usaha sadar dan terencana untuk mewujudkan suasana belajar dan proses pembelajaran agar peserta didik secara aktif mengembangkan potensi dirinya untuk memiliki kekuatan spiritual keagamaan, pengendalian diri, kepribadian, kecedasan, akhlak mulia serta keterampilan yang diperlukan dirinya dan masyarakat.

Pendidikan merupakan suatu proses pembelajaran terhadap manusia secara terus menerus, agar manusia tersebut menjadi pribadi yang amil (sempurna) lahir dan batin 1 . Karena itu jika pendidikan menghasilkan pribadipribadi yang lemah, doyan KKN, tidak bertanggungjawab, tidak bermoral, dan tidak mandiri, maka berarti program pendidikan itu gagal. Kegagalan tersebut mungkin disebabkan karena adanya kesalahan dalam filosofi maupun

1 Juwono Sudarsono, 2008 Pendidikan, Kemanusiaan, dan Peradaban dalam Landasan dan Arah Pendidikan Nasional Kita, Soedijarto. Kompas;Jakarta. Hal. xvii 
manajemen pendidikan sehingga tidak sesuai dengan cita-cita pendidikan itu sendiri. Belakangan ini kita melihat berbagai masalah pendidikan nasional sering menjadi bulan-bulanan kritik di masyarakat. Kenapa pendidikan di Indonesia tidak menghasilkan pribadi-pribadi yang unggul dalam ilmu pengetahuan, akhlak, dan kemanusiaan? Kita melihat sendi-sendi kehidupan bangsa saat ini tengah digoyang berbagai macam aksi kekerasan, kerusuhan, anarki, korupsi, vandalisme, dan tindakan-tindakan amoral.

Pendidikan tampaknya kurang diarahkan untuk memanusiakan manusia secara utuh lahir dan batin, tetapi lebih diorientasikan pada hal-hal yang bersifat materialistis, ekonomis, dan teknokratis, kering dari sentuhan nilai-nilai moral, kemanusiaan, dan budi pekerti. Pendidikan lebih mementingkan kecerdasan intelektual, akal, dan penalaran, tanpa diimbangi dengan intensifnya pengembangan kecerdasan hati, perasaan, dan emosi. Akibatnya, apresiasi output pendidikan terhadap keunggulan nilai humanistis, keluhuran budi, dan hati nurani menjadi dangkal, serta tidak banyak yang menjadi sosok pribadi yang telah kehilangan hati nurani dan perasaan, cenderung egoistis dan bersikap aji mumpung. ${ }^{2}$

Dalam konteks yang demikian itu pendidikan kita dianggap telah melahirkan manusia-manusia berkarakter oportunistis, penjilat, hipokrit, hedonis, besar kepala, tanpa memiliki kecerdasan hati, emosi, dan nurani. Tidaklah mengherankan jika kasus-kasus yang merugikan negara, KKN misalnya, justru sering melibatkan orang-orang berdasi yang cecar formal berpendidikan tinggi. Ini artinya, secara implisit, model pendidikan kita selama ini setidaknya telah memiliki andil terhadap maraknya korupsi, kolusi, dan nepotisme yang menyebabkan negara kita tergolong sebagai salah satu negara yang tingkat korupsinya tertinggi di dunia. Makna pendidikan yang hakiki merujuk pada sebuah kondisi yang mampu memberikan ruang kesadaran bagi peserta didik untuk mengembangkan jati dirinya melalui sebuah proses yang menyenangkan, terbuka, dan tidak terbelenggu dalam suasana monoton, kaku, dan menegangkan. Diakui atau tidak, pendidikan kita selama ini belum sanggup melahirkan generasi yang utuh jati dirinya. Mereka memang cerdas tetapi kehilangan sikap jujur rendah hati. Mereka terampil, tetapi kurang menghargai sikap tenggang rasa dan toleransi. Imbasnya, nilai-nilai kesalehan, baik individu maupun sosial, menjadi sirna.

Kemajuan suatu bangsa sangat ditentukan oleh kualitas pendidikan. Oleh karena itu, pendidikan sebagai sarana untuk mencerdaskan kehidupan bangsa memiliki peranan yang sangat strategis. Pendidikan berkontribusi dalam mengembangkan sumber daya manusia (SDM) yang bermutu, dengan indikator berkualifikasi ahli, terampil, kreatif, inovatif, serta memiliki attitude (sikap dan perilaku) yang positif. ${ }^{3}$ Amanat Pembukaan UUD 1945 dan visi pendidikan nasional merujuk pada suatu landasan filsafat yang amat mendalam, yang dalam pasal 31 Ayat 1 UUD 1945 dinyatakan sejalan dengan Hak Asasi Manusia untuk belajar. Ini berarti bahwa secara legal System pendidikan dilandasi oleh suatu filsafat pendidikan yang mendalam yang mengakui perbedaan unik pribadi individu. Artinya, keragaman, martabat, serta peradaban nilai dalam

2 Ibid, hal. xix

${ }^{3}$ Herman Suparno, 2008, Pendidikan, Kemanusiaan, dan Peradaban dalam Landasan dan Arah Pendidikan Nasional Kita, Soedijarto. Kompas;Jakarta. Hal. xxiii 
pertumbuhan anak Indonesia secara implisit mengandung peluang untuk mewujudkan asas eksplorasi dan kecenderungan kreatif dalam seluruh tumbuh kembangnya. Hal tersebut telah diulangi dalam Undang-Undang Nomor 20 Tahun 2003 tentang Sistem Pendidikan Nasional (Pasal5).

Selain itu juga, media pembelajaran berupa buku-buku paket pelajaran yang digunakan dalam proses belajar mengajar sangat sedikit yang memuat secara langsung materi permasalahan korupsi.

Upaya pencegahan budaya korupsi di masyarakat terlebih dahulu dapat dilakukan dengan mencegah berkembangnya mental korupsi pada anak bangsa Indonesia melalui pendidikan. Hal ini disadari bahwa memberantas korupsi juga tak lepas dari gerakan preventif, yaitu mencegah timbulnya mental korupsi pada generasi anak bangsa. Mengingat upaya pencegahan tersebut tidak hanya dapat dilakukan pada satu generasi saja, melainkan dua atau tiga generasi selanjutnya.

Pendidikan Anti Korupsi bagi mahasiswa bertujuan untuk memberikan pengetahuan yang cukup tentang seluk beluk korupsi dan pemberantasannya serta menanamkan nilai-nilai anti korupsi. Tujuan jangka panjangnya adalah menumbuhkan budaya anti korupsi di kalangan mahasiswa dan mendorong mahasiswa untuk dapat berperan serta aktif dalam upaya pemberantasan korupsi di Indonesia.

Komisi Pemberantasan Korupsi (KPK) dalam Undang-Undangnya menjelaskan bahwa salah satu kewenangannya adalah tataran upaya penindakan dan pencegahan, disamping kewenangan-kewenangan lain yang menjadi tugas pokoknya. Pemerintah melalui Kementerian Pendidikan dan Kebudayaan Direktorat Jenderal Pendidikan Tinggi pada tanggal 30 Juli 2012 telah mengeluarkan surat edaran nomor 1016/E/T/2012 kepada seluruh Perguruan Tinggi Negeri dan Perguruan Tinggi Swasta (Kopertis Wilayah I sampai dengan wilayah XII), dengan perihal Surat Edaran Tentang Implementasi Pendidikan Anti Korupsi di Perguruan Tinggi. Adapun dasar dikeluarkannya surat edaran ini merujuk pada Instruksi Presiden RI Nomor 17 Tahun 2011 tentang Aksi Pencegahan dan Pemberantasan Korupsi Tahun 2012.

Dalam upaya pelaksanaan pencegahan dan pemberantasan korupsi sebagaimana diamanatkan dalam Peraturan Presiden Nomor 55 Tahun 2012 tentang Strategi Nasional Pencegahan dan Pemberantasan Korupsi Jangka Panjang Tahun 2012-2025 dan Jangka Menengah Tahun 2012-2014 (Stranas PPK), dan sebagai implementasinya dilakukan penyusunan aksi Pencegahan dan Pemberantasan Korupsi (PPK) setiap tahun yang selanjutnya dikeluarkan Instruksi Presiden Nomor 2 Tahun 2014 tentang Aksi Pencegahan dan Pemberantasan Tindak Pidana Korupsi Tahun 2014, dimana dalam lampiran Inpres tersebut pada bagian ke $\mathrm{V}$ (lima) diterangkan tentang strategi pendidikan dan budaya anti korupsi yang terdiri atas 22 rencana aksi, dan diantaranya melibatkan lembaga pendidikan tinggi negeri dan swasta dalam pengimplementasiannya.

Berdasarkan uraian diatas, yang menjadi pokok bahasan dalam karya tulis ini adalah: (1) bagaimana arah kebijakan pendidikan anti korupsi di Indonesia? (2) sejauhmana kebijakan pendidikan anti korupsi dalam upaya pencegahan tindak pidana korupsi?. 


\section{KAJIAN TEORI}

Sebelum lebih jauh membahas mengenai kebijakan pendidikan anti korupsi alangkah baiknya dipaparkan terlebih dahulu mengenai teori dan konsep kebijakan pendidikan anti korupsi itu sendiri;

\section{A. Hukum dan Perilaku}

Manusia tidak memulai kehidupan bersamanya dengan membuat sistem hukum, melainkan membangun suatu masyarakat. Baru dari kehidupan bersama yang bernama masyarakat itu dilahirkan hukum. Masyarakat itulah yang menjadi wadah sekalian aktivitas para anggotanya. Maka pekerjaan rumah pertama adalah membangun suatu kehidupan bersama diatas individu para anggotanya. ${ }^{4}$

Semakin hukum menjorok masuk ke dalam era modern, maka ia semakin mengukuhkan dirinya sebagai teknologi. Faktor penting yang menyebabkan hal tersebut adalah campur tangan manusia yang semakin aktif dalam menggunakan hukum itu untuk tujuan-tujuan tertentu. Efek perlucutannya terhadap kekuasaan-keuasaan otoriter yang memerintah dengan cara-cara ad hoc, untuk digantikan oleh negara hukum, menjadikan hukum sebagai sarana yang sah, diandalkan dan dicari untuk menjalankan kekuasaan. Muncul adagium "The rule of law not of man". Sekalipun putusan-putusan dalam masyarakat menjadi sah manakala diberi baju hukum. ${ }^{5}$ Peraturan (rule) juga mengalami perubahan jati diri penting, yaitu tidak lagi sebagai peraturan moral melainkan lebih sebagai instrumen dan teknologi untuk mewujudkan suatu kepentingan secara sah (legal).

Hukum sebagai institusi moral bertumpu pada perilaku manusia yang baik. Di sini, hukum bagaikan mengajukan persyaratan, bahwa untuk menciptakan kehidupan hukum yang baik maka para anggota masyarakat harus hidup dengan baik. Tetapi apabila hukum sudah lebih menjadi teknologi, maka persyaratan tersebut tidak diperlukan. Tekanan dalam berhukum berubah menjadi bagaimana cara untuk dapat menggunakan teknologi tersebut dengan baik dan berhasil. 6

\section{B. Kesadaran dan Ketaatan Hukum}

Sosiologi hukum sangat berperan dalam upaya sosialisasi hukum demi meningkatkan kesadaran hukum yang positif, baik dari warga masyarakat secara keseluruhan, maupun dari kalangan penegak hukum. Sebagaimana diketahui bahwa kesadaran hukum ada dua macam 7 :

a. Kesadaran hukum positif, identik dengan "ketaatan hukum".

b. Kesadaran hukum negatif, identik dengan "ketidaktaatan hukum".

Menurut Ewick dan Silbey 8 tentang legal consciousness (kesadaran hukum) sebagi berikut: "The term legal consciousnessis used by social scientist to refer to ways in which people make sense of law and legal institutions, that is, The understandings which give meaning to people's experiences and actions".

\footnotetext{
4 Sajipto Rahadjo, 2009. Hukum dan Perilaku. Kompas:Jakarta. Hal. 5

5 Ibid. Hal. 57

6 Ibid. Hal. 59

7 Achmad Ali, 2009. Menguak Teori Hukum dan Teori Peradilan Vol 1. Kencana:Jakarta. Hal. 298

8 Ibid. Cotteral, 2001. Hal. 6-7
} 
Jadi istilah kesadaran hukum digunakan oleh para ilmuwan sosial untuk mengacu ke cara-cara dimana orang-orang memaknakan hukum dan institusiinstitusi hukum, yaitu pemahaman-pemahaman yang memberikan makna kepada pengalaman dan tindakan orang-orang.

Bagi Ewick dan Silbey kesadaran hukum terbentuk dalam tindakan dan karenanya merupakan persoalan praktisi untuk dikaji secara empiris. Dengan kata lain, kesadaran hukum adalah persoalan "hukum sebagai perilaku", dan bukan "hukum sebagai aturan, norma, atau asas".

\section{Pendidikan dan Kesadaran Hukum}

Sistem pendidikan kita kiranya kurang menaruh perhatiannya dalam menanamkan pengertian tentang kesadaran hukum. Mengingat bahwa hukum adalah perlindungan kepentingan manusia, maka menurunnya kesadaran hukum masyarakat disebabkan karena orang tidak melihat atau menyadari lagi bahwa hukum melindungi kepentingannya. ${ }^{9}$ Soerjono Soekanto menambahkan bahwa menurunnya kesadaran hukum masyarakat disebabkan juga karena para pejabat kurang menyadari akan kewajibannya untuk memelihara hukum dan kurangnya pengertian akan tujuannya serta fungsinya dalam pembangunan.

Tindakan atau cara apakah yang sekirarnya efektif untuk meningkatkan kesadaran hukum masyarakat? Tindakan drastis dengan misalnya memperberat ancaman hukum atau dengan lebih mengetatkan penataan ketaatan warga negara terhadap undang-undang saja, yang hanya bersifat insidentil dan kejutan, kiranya bukanlah merupakan tindakan yang tepat untuk meningkatkan kesadaran hukum masyarakat. Mungkin untuk beberapa waktu lamanya akan tampak atau terasa adanya penertiban tetapi kesadaran hukum masyarakat tidak dapat dipaksakan dan tidak mungkin diciptakan dengan tindakan yang drastis yang bersifat insidentil saja.

Hukum merupakan pencerminan nilai-nilai yang terdapat di dalam masyarakat. Menanamkan kesadaran hukum berarti menanamkan nilai-nilai kebudayaan. Dan nilai-nilai kebudayaan dapat dicapai dengan pendidikan. Oleh karena itu setelah mengetahui kemungkinan sebab-sebab merosotnya kesadaran hukum masyarakat usaha peningkatan dan pembinaan yang utama, efektif dan efisien ialah dengan pendidikan.

Pendidikan tidaklah merupakan suatu tindakan yang "einmalig" atau insidentil sifatnya, tetapi merupakan suatu kegiatan yang kontinyu dan intensif dan terutama dalam hal pendidikan kesadaran hukum ini akan memakan waktu yang lama. Kiranya tidak berlebihan kalau dikatakan bahwa dengan pendidikan yang intensif hasil peningkatan dan pembinaan kesadaran hukum baru dapat kita lihat hasilnya yang memuaskan sekurang-kurangnya 18 atau 19 tahun lagi. Ini bukan suatu hal yang harus kita hadapi dengan pesimisme, tetapi harus kita sambut dengan tekad yang bulat untuk mensukseskannya. Dengan pendidikan sasarannya akan lebih kena secara intensif daripada cara lain yang bersifat drastis.

\footnotetext{
9 Agung Nugroho. Kesadaran Hukum Masyarakat. Pada agungnugroho.dosen.narotama.ac.id
} 


\section{Peran Perguruan Tinggi}

Pentingnya peran perguruan tinggi sebagai penjaga dan pengembang integritas bangsa, bukan saja sebagai bagian dari gerakan antikorupsi. Pada saat yang sama institusi pendidikan ini bisa menjadi tonggak bagi pembangunan akuntabilitas dan transparansi. Perguruan tinggi bisa menjadi motor penggerak integritas karena mampu berperan penting memberhentikan "supply" koruptor di negeri ini.

Memerangi korupsi melalui pendayagunaan jalur pendidikan formal sebagai suatu bagian menangani korupsi merupakan salah satu strategi yang diharapkan cukup signifikan, mengingat masyarakat terdidik inilah yang perannya dimasyarakat cukup dominan. Mereka tidak cukup hanya dibekali pengetahuan dan kemampuan bagaimana melakukan sesuatu pekerjaan atau jabatan dalam masyarakat, tetapi yang lebih utama adalah bagaimana menggunakan ilmu dan cara-cara tersebut dengan benar, tanpa harus melakukan korupsi, bahkan termasuk kiat-kiat untuk melawan korupsi, dorongan atau motivasi untuk aktif berperan dalam upaya memerangi atau memberantas korupsi10.

Tujuan pemberian materi PAK bagi mahasiswa adalah agar mereka mendapatkan pengetahuan yang cukup tentang seluk beluk korupsi dan pemberantasannya serta menanamkan nilai-nilai anti korupsi sejak dini sehingga berkembang integritas diri dan lembaga. Dengan begitu diharapkan akan tumbuh budaya anti-korupsi di kalangan mahasiswa dan perguruan tinggi yang mendorong segenap unsur perguruan tinggi dapat berperan serta aktif dalam gerakan anti korupsi. Tujuan jangka panjangnya adalah bisa menghasilkan generasi penerus, sarjana lulusan perguruan tinggi yang tidak "catat nilai", profesional dan berintegritas serta memiliki komitmen kuat pada upaya pencegahan dan pemberantasan korupsi di Indonesia.

Tantangan besar perguruan tinggi kita saat ini adalah mengembalikan pendidikan pada fungsinya sebagai pembentuk karakter bangsa yang tidak hanya bertugas sebagai wahana transfer ilmu pengetahuan dan teknologi, penguasaan keterampilan dan seni, tetapi juga membangun semangat dan kompetensinya sebagai agent of change bagi kehidupan bermasyarakat, berbangsa dan bernegara yang bersih dan bebas dari ancaman korupsi. ${ }^{11}$

\section{METODE PENELITIAN}

Domain penelitian ini berada dalam ranah ilmu hukum dengan jenis pendekatan yang digunakan adalah pendekatan normative. Pendekatan ini mengkaji hal-hal yang menggunakan konsep legis positivis yang menyatakan bahwa hukum adalah identik dengan norma-norma tertulis yang dibuat dan diundangkan oleh lembaga-lembaga atau pejabat yang berwenang. Selain itu konsep ini juga memandang hukum sebagai sistem normatif yang bersifat otonom, tertutup dan terlepas dari kehidupan masyarakat.

\footnotetext{
10 Tim LP3 UMY, 2004: 212. Pada Wayan Gede Suacana. Pendidikan Anti-Korupsi Di Perguruan Tinggi. Akses di wgsuacana.files.wordpress.com

11 ibid
} 


\section{PEMBahasan}

Setiap Perguruan Tinggi diharapkan untuk menyelenggarakan Pendidikan Anti Korupsi mulai tahun akademik baru 2012/2013 dalam bentuk Mata Kuliah Wajib/Pilihan atau disisipkan dalam mata kuliah yang relevan. Dengan demikian, mahasiswa baru tahun ini menjadi kelinci percobaan dari sebuah kebijakan. Semoga itu bukan kebijakan dadakan atau instan.

Kebijakan Kemdikbud tersebut turut melibatkan Komisi Pemberantasan Korupsi (KPK) untuk menyusun materi kuliahnya. Langkah pun sudah dimulai dengan kegiatan Training of Trainers (TOT) Pendidikan Anti Korupsi Tahun 2012. Pesertanya adalah 1007 Dosen di 526 Perguruan Tinggi di seluruh Indonesia. Selanjutnya, 92 PTN dan 434 PTS diharapkan mengimplementasikannya pada tahun akademik baru.

Korupsi berdasarkan pemahaman pasal 2 Undang-Undang Nomor 31 Tahun 1999 yang diubah menjadi Undang-Undang Nomor 20 Tahun 2001 merupakan tindakan melawan hukum untuk memperkaya diri sendiri/orang lain (perseorangan atau sebuah korporasi), yang secara langusng maupun tidak langsung merugikan keuangan atau prekonomian negara, yang dari segi materiil perbuatan itu dipandang sebagai perbuatan yang bertentangan dengan nilainilai keadilan masyarakat.

Anti Korupsi merupakan semua tindakan yang melawan, memberantas, menentang, dan mencegah korupsi. Pendidikan dan Budaya Anti Korupsi merupakan upaya memberikan pemahaman dan penanaman nilai-nilai kepada sektor swasta, masyarakat, dan aparat pemerintah agar berperilaku anti korupsi.

Dalam dunia akademis khususnya perguruan tinggi, lahirnya sebuah matakuliah baru akan memerlukan penempatan ranah keilmuan yang tepat. Demikian pula halnya dengan matakuliah Anti-korupsi. Dari pengalaman beberapa universitas yang telah menyelenggarakan matakuliah ini, selalu muncul pertanyaan, diskusi hingga perdebatan mengenai berada di ranah keilmuan manakah matakuliah Anti-korupsi. Perdebatan biasanya berlangsung di antara beberapa bidang keilmuan, dan berujung pada kesulitan untuk memperoleh titik temu, oleh karena setiap keilmuan cenderung mempertahankan perspektifnya masing-masing.

Sebuah topik yang diangkat dalam sebuah matakuliah atau bahkan menjadi penamaan dari sebuah matakuliah tidak selalu berasal dari keilmuan itu sendiri, namun sangat mungkin lahir sebagai respon atas perkembangan fenomena yang terjadi. Begitu pula matakuliah Anti-korupsi yang bisa dikatakan lahir dari adanya fenomena semakin parahnya disintegritas dalam kehidupan berbangsa dan bernegara, yang diindikasikan oleh terjadinya berbagai tindak korupsi yang tiada henti, sehingga memerlukan upaya- upaya sistematis dalam membasminya. Dampak korupsi yang telah terbukti melemahkan sumber daya, meresahkan kehidupan sosial, menggerogoti potensi negara-bangsa dan bahkan sudah menjadi masalah internasional, harus di diseminasikan kepada seluruh masyarakat melalui pendidikan; sehingga diharapkan akan menumbuhkan tekad bersama untuk menghentikan korupsi dimasa mendatang. 
Pendidikan anti korupsi dalam bentuk mata kuliah khusus seolah menjadikan korupsi sebagai pengetahuan, atau setidaknya bahan telaah para dosen dan mahasiswa. Bedanya, harapannya adalah pengetahuan tersebut bukan untuk diterapkan, namun dihindari. Siapa tahu terwujud tekad kolektif untuk tidak ikut-ikutan korupsi saat lulus nanti, termasuk korupsi yang justru terjadi di perguruan tinggi itu sendiri. Bersih-bersih diri dan rumah sendiri jauh lebih penting daripada menelisik teksonomi korupsi di perguruan tinggi.

Melalui pendidikan anti korupsi inilah nantinya bisa menjadi bekal bagi mahasiswa untuk bertindak jujur dalam bekerja. Tentunya, agar tidak melakukan tindakan korupsi ketika nanti menduduki posisi strategis di sebuah

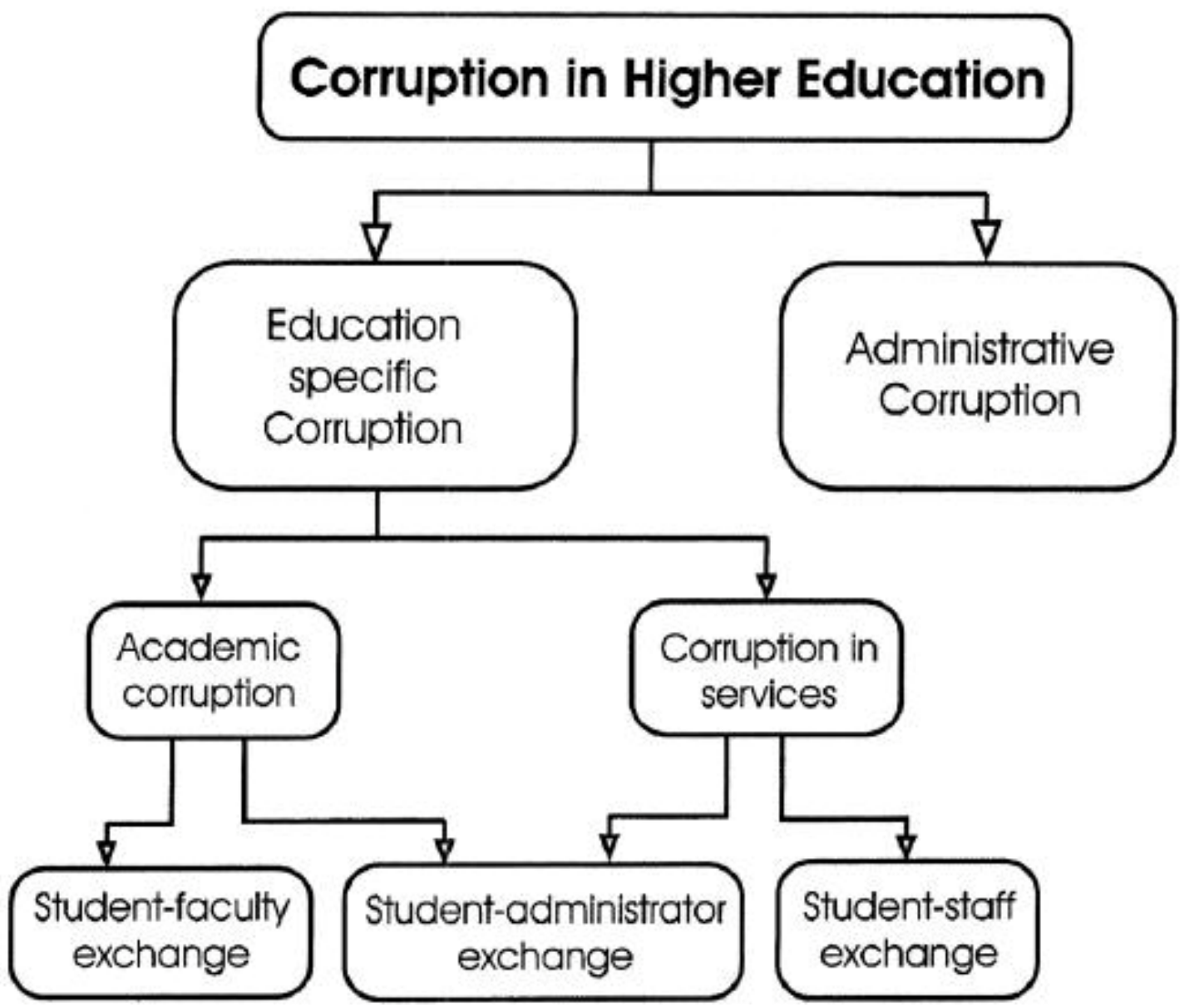

institusi atau menjabat posisi penting di birokrasi ini. Fakta menunjukkan bahwa orang berpendidikan tinggi rentan terhadap godaaan korupsi karena mereka biasanya menduduki posisi strategis di sebuah institusi atau menjabat posisi penting di birokrasi. Karenanya penting pendidikan korupsi di perguruan tinggi. 
Pada dasarnya, pendidikan Antikorupsi sebaiknya dapat digalakkan sejak dini. Pemberian pendidikan antikorupsi di Indonesia sejak dini akan memberikan tindakan preventif bagi pemberantasan korupsi di Indonesia. Penanaman akan nilai-nilai kebenaran dan menghindari perbuatan-perbuatan terlarang seperti korupsi juga akan dapat mengubah pola kehidupan masyarakat yang sebelumnya terlalu "toleran" terhadap korupsi menjadi semangat antikorupsi yang berdampak besar bagi bangsa Indonesia.

Dengan adanya pendidikan Antikorupsi, para pelajar Indonesia tentu dapat menjadi garda terdepan pemberantasan korupsi di Indonesia. Pelajar akan mampu menularkan semangat Antikorupsi kepada masyarakat di sekitarnya sehingga proses pemberantasan serta pencegahan kembali terjadinya korupsi

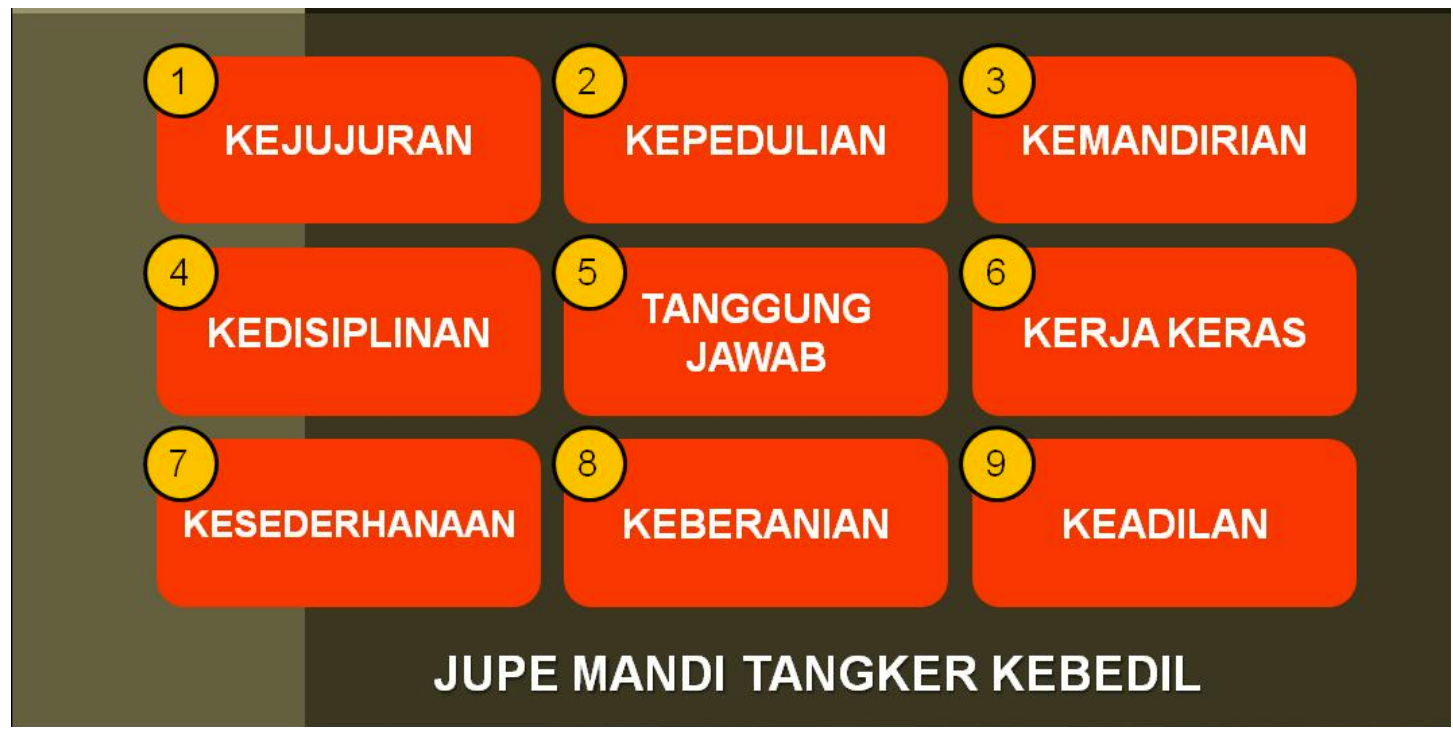

dapat berjalan dengan baik. Dukungan masyarakat yang optimal dalam pemberantasan korupsi juga tentu akan berdampak signifikan bagi upaya pemberantasan korupsi di Indonesia. Dengan adanya dukungan optimal dari masyarakat, pemerintah serta KPK dapat menyinergikan kekuatan dalam proses pemberantasan korupsi serta upaya pencegahan munculnya bibit-bibit korupsi baru dalam masyarakat. Mari kita wujudkan pendidikan antikorupsi di Indonesia sebagai dasar pemberantasan korupsi di Indonesia demi masa depan Indonesia yang lebih baik.

Dalam upaya pelaksanaan pencegahan dan pemberantaran korupsi sebagaimana diamanatkan dalam Peraturan Presiden Nomor 55 Tahun 2012 tentang Strategi Nasional Pencegahan dan Pemberantasan Korupsi (Stranas PPK) Jangka Panjang (2012-2015) dan Jangka Menengah (2012-2014), yang diimplementasikan melalui aksi Pencegahan dan Pemberantasan Korupsi (PPK), Presiden Susilo Bambang Yudhoyono pada 21 Maret 2014 telah menandatangani Instruksi Presiden Nomor 2 Tahun 2014tentang Aksi Pencegahan dan Pemberantasan Korupsi Tahun 2014.

Instruksi ini ditujukan kepada para menteri Kabinet Indonesia Bersatu II; Sekretaris Kabinet; Jaksa Agung; Kepala Kepolisian Negara Republik Indonesia (Kapolri); Kepala Unit Kerja Presiden Bidang Pengawasan dan Pengendalian Pembangunan (UKP4); para Kepala Lembaga Pemerintah Non Kementerian 
(LPNK); para Sekretaris Jendral pada Lembaga Tinggi Negara; para Gubernur; dan para Bupati/Walikota.

Kepada para pejabat tersebut, Presiden menginstruksikan agar menyusun aksi PPK Tahun 2014, dengan berpedoman pada Visi dan Misi serta Fokus Kegiatan Prioritas Jangka Menengah Stranas PPK 2012-2014, dan disesuaikan dengan situasi serta kondisi dari masing-masing Kementerian/Lembaga dan Pemerintahan Daerah.

"Aksi PPK Tahun 2014 itu, disusun dalam rangka mempercepat pelaksanaan program dan kegiatan prioritas pembangunan yang tertuang dalam Rencana Pembangunan Jangka Menengah Nasional 2010-2014, Rencana Pembangunan Jangka Menengah Daerah masing-masing, Rencana Kerja Pemerintah Tahun 2014, dan Rencana Kerja Pemerintah Daerah Tahun 2014," bunyi instruksi kedua Inpres tersebut.

Presiden SBY menegaskan, agar Aksi PPK Tahun 2014 berpedoman pada strategi-strategi: 1. Pencegahan; 2. Penegakan Hukum; 3. Peraturan Perundangundangan; 4. Kerjasama Internasional dan Penyelamatan Aset Hasil Korupsi; 5. Pendidikan dan Budaya Anti Korupsi; dan 6. Mekanisme Pelaporan.

Melalui Inpes No. 2/2014 ini, Presiden memerintahkan Menko Polhukam berkoordinasi bersama Menko Kesra dan Menko Perekonomian untuk menyusun prioritas Aksi PPK berdasarkan 6 (enam) strategi di atas.

Sementara kepada para menteri Kabinet Indonesia Bersatu II, Sekretaris Kabinet, Jaksa Agung, Kapolri, Kepala UKP4, para Kepala LPNK, para Sekretaris Jendral Lembaga Negara, para Gubernur, dan para Bupati/Walikota, Presiden SBY meminta agar melaksanakan Aksi PPK sebagai terlampir dalam Instruksi Presiden Nomor 2 Tahun 2014 itu.

Terkait dengan pelaksanaan Inpres tersebut, Presiden menegaskan semua Kementerian dan LPNK wajib berkoordinasi dengan Menteri Perencanaan Nasional/Kepala Badan Perencanaan Pembangunan Nasional (Bappenas). Sementara semua Pemerintah Daerah Provinsi dan Kabupaten/Kota wajib berkoordinasi dengan Menteri Dalam Negeri (Mendagri), serta didukung oleh Menteri Perencanaan Pembangunan Nasional/ Kepala Bappenas.

Melalui Inpres tersebut, Presiden menginstruksi Menteri Perencanaan Pembangunan Nasional/Kepala Bappenas untuk melakukan koordinasi dalam menyiapkan rumusan Aksi PPK Tahun 2014, melakukan pemantauan dan evaluasi secara berkala yang didukung oleh Kepala UKP4, serta berdasarkan input prioritas aksi yang diperoleh dari Komisi Pemberantasan Korupsi (KPK), Bank Indonesia (BI), Pusat Pelaporan dan Analisis Transaksi Keuangan (PPATK), Ombudsman Republik Indonesia, Lembaga Perlindungan Saksi dan Korban (LPSK), Badan Pemeriksa Keuangan (BPK), Komisi Yudisial, dan Mahkamah Agung.

"Menteri Perencanaan Pembangunan Nasional/Kepala Bappenas melaporkan hasilnya (penyiapan rumusan aksi, pemantauan dan evaluasi) kepada Presiden," tegas instruksi kedelapan dalam Inpres tersebut.

Presiden juga menginstruksikan Mendagri untuk melakukan koordinasi dalam menyiapkan rumusan Aksi Daerah Pencegahan dan Pemberantasan Korupsi, serta pemantauan dan evaluasi kemajuan secara berkala didukung oleh Menteri Perencanaan Pembangunan Nasional/Kepala Bappenas.

Terkait dengan kebijakan pendidikan anti korupsi diantara 22 rencana aksi yang dipaparkan terdapat 4 rencana aksi yang melibatkan peran Perguruan 
Tinggi dalam pengimplementasiannya, baik implementasi dalam konten pembelajaran, interaksi antar lembaga, sosialisasi, sampai pada pendidikan non formal.

Di era reformasi seperti sekarang ini, masih jarang dijumpai masyarakat secara individual yang memiliki keberanian mengungkap kasus korupsi. Korupsi yang sudah dilakukan secara sistematis dan terorganisir mungkin adalah salah satu penyebab ketakutan setiap orang untuk membedah tindak korupsi. Siapa yang 'berontak' akan sangat mungkin malah tersisihkan. Hal ini tentunya akan berujung pada keterbatasan ruang gerak si pembedah korupsi. Salah satu contoh praktek korupsi yang licin untuk dibuktikan adalah saat penerimaan calon pegawai negeri. Praktek-praktek korupsi terdengar di mana-mana, namun, begitu sulit untuk dibuktikan di meja hijau. Bahkan kasusnyapun jarang sampai ke gerbang kantor penegak hukum. Tidak ada seorangpun yang nampaknya berani mengungkap kasus ini. Ironisnya, pelajar yang dalam hal ini dikategorikan sebagai orang terdidik tidak mampu berbuat banyak. Bahkan terkesan mengikuti arus permainan. Ketakutan dan kecemasan tentunya muncul ketika seseorang dihadapkan pada sebuah sistem yang kukuh. Ketakutan dan kecemasan itu muncul karena adanya ancaman terhadap nilai eksistensi dasar manusia (Teori Rollo May dalam Friedman dan Schustack) ${ }^{12}$. Siapa yang patut dipersalahkan? Pemerintah, lembaga hukum, ataukah dunia pendidikan yang belum mampu memberikan bekal 'keberanian' dan 'kesetiaan' akan kejujuran? Di sini pendidikan sering menjadi komponen yang paling disoroti.

Pendidikan antikorupsi sesungguhnya abstrak, bukan melalui logika saja. Pendidikan ini memerlukan tahap penalaran, internalisasi nilai dan moral, sehingga mata pelajarannya didesain tidak hanya menekankan aspek kognitif, melainkan lebih pada aspek afektif dan psikomotorik. ${ }^{13}$ Menekankan bagaimana agar anak didik melakukan sesuatu, atau menghindari sesuatu untuk mendapat pengharagaan sosial dari orang lain. Bagi anak-anak, proses penalaran moral berkembang sejalan dengan proses belajar sendiri dan belajar dari lingkungan. Melalui pendidikan antikorupsi yang terarah dan efektif, terbuka kemungkinan internalisasi nilai-nilai. Peran Guru dan Dosen, orang tua, dan orang-orang di sekitar menjadi kunci. Mereka harus memberi teladan berperilaku antikorupsi, terutama berperilaku jujur sebagai dasar pembentukan karakter secara dini.

Program Pendidikan Anti Korupsi bertujuan untuk memberikan pemahaman yang sama dan terpadu serta terbimbing dalam rangka menekan kerugian negara yang disebabkan oleh tindakan korupsi. Kemudian harapannya berdampak pada adanya respon atau tanggapan balik dari rakyat untuk bisa menyuarakan kearifannya mengenai penyimpangan korupsi. Di samping itu juga bertujuan untuk membentuk kesadaran publik terhadap setiap kegiatan yang mengarah kepada adanya tindakan korupsi oleh para penguasa atau pengambil kebijakan yang tidak mempedulika rakyat. ${ }^{14}$

Sejumlah alasan pun dilontarkan untuk menunjukkan dibutuhkannya Pendidikan Anti Korupsi untuk menyikapi realita. Pertama, pendidikan lebih dominan berorientasi pada penguasaan iptek, sedangkan sesuatu yang

12 Friedman, Howard S. dan Mariam W. Schustrack. 2006. Kepribadian: Teori Klasik dan Riset Modern. Jakarta: Erlangga.

13 http://www.riaumandiri.net

14 Tim MCW dalam http://niamw.wordpress.com 
menyangkut budaya dan perilaku (karakter) relatif masih terabaikan. Artinya, integrasi antara pendidikan iptek dan seni dengan moral dan etika belum dapat dilakukan secara serasi dan seimbang. Oleh karena itu, hadirnya Pendidikan Anti Korupsi dipandang sebagai pembaharuan yang tepat bagi pendidikan di Indonesia.

Pendidikan antikorupsi bagi mahasiswa/siswa mengarah pada pendidikan nilai, yaitu nilai-nilai kebaikan. Suseno (dalam Djabbar, 2009) 15 berpendapat bahwa pendidikan yang mendukung orientasi nilai adalah pendidikan yang membuat orang merasa malu apabila tergoda untuk melakukan korupsi, dan marah bila ia menyaksikannya. Menurut Suseno, ada tiga sikap moral fundamental yang akan membuat orang menjadi kebal terhadap godaan korupsi. Ketiga sikap moral fundamental tersebut adalah kejujuran, rasa keadilan, dan rasa tanggung jawab.

Jujur berarti berani menyatakan keyakinan pribadi, menunjukkan siapa dirinya. Kejujuran adalah modal dasar dalam kehidupan bersama. Ketidakjujuran jelas akan menghancurkan komunitas bersama. Mahamahasiswa/siswa/mahasiswa/siswa perlu belajar bahwa berlaku tidak jujur adalah sesuatu yang amat buruk.

Adil berarti memenuhi hak orang lain dan mematuhi segala kewajiban yang mengikat diri sendiri. Magnis (dalam Djabbar, 2009)16 mengatakan bahwa bersikap baik tetapi melanggar keadilan, tidak pernah baik. Keadilan adalah tiket menuju kebaikan. Sikap moral yang selanjutnya dibutuhkan adalah rasa tanggung jawab. Tanggung jawab berarti teguh hingga terlaksananya tugas. Tekun melaksanakan kewajiban sampai tuntas. Misalnya, mahamahasiswa/siswa/mahasiswa/siswa diberi tanggung jawab mengelola dana kegiatan olahraga di sekolahnya. Rasa tanggung jawab mahamahasiswa/siswa/mahasiswa/siswa terlihat ketika dana dipakai seoptimal mungkin menyukseskan kegiatan olahraga.

Alasan kedua yang dilontarkan untuk mendukung Pendidikan Anti Korupsi masuk kurikulum adalah melaui Pendidikan Anti Korupsi para mahasiswa/siswa sejak usia dini sudah mengetahui tentang seluk-beluk praktek korupsi sekaligus konsekuensi yang akan diterima oleh para pelaku. Ketiga, memberikan proses pembelajaran tentang kepakaan terhadap praktekpraktek korupsi yang ada disekitar kita. Keempat, mendidik para mahasiswa/siswa dari usia dini tentang akhlak atau moral yang sesuai dengan ajaran-ajaran sosial keagamaan. Kelima, menciptakan generasi penerus yang bersih dari perilaku penyimpangan, dan keenam, membantu seluruh cita-cita warga bangsa dalam menciptakan clean and good-goverment demi masa depan yang lebih baik dan beradab.

\section{PENUTUP}

Berdasarkan uraian diatas maka dapat disimpulkan bahwa:

1. Pemerintah melalui Kementerian Pendidikan dan Kebudayaan Direktorat Jenderal Pendidikan Tinggi pada tanggal 30 Juli 2012 telah mengeluarkan surat edaran nomor 1016/E/T/2012 kepada seluruh Perguruan Tinggi

15 Djabbar, Faisal. 2009. Tentang Kurikulum Antikorupsi dalam http://smk3ae.wordpress.com/2009/02/02/tentang-kurikulum-antikorupsi-2/. Diakses 5 Desember 2012. 16 ibid 
Negeri dan Perguruan Tinggi Swasta (Kopertis Wilayah I sampai dengan wilayah XII), dengan perihal Surat Edaran Tentang Implementasi Pendidikan Anti Korupsi di Perguruan Tinggi. Adapun dasar dikeluarkannya surat edaran ini merujuk pada Instruksi Presiden RI Nomor 17 Tahun 2011 tentang Aksi Pencegahan dan Pemberantasan Korupsi Tahun 2012.

2. Pendidikan antikorupsi bagi mahasiswa/siswa mengarah pada pendidikan nilai, yaitu nilai-nilai kebaikan. Pendidikan yang mendukung orientasi nilai adalah pendidikan yang membuat orang merasa malu apabila tergoda untuk melakukan korupsi, dan marah bila ia menyaksikannya. Ada tiga sikap moral fundamental yang akan membuat orang menjadi kebal terhadap godaan korupsi. Ketiga sikap moral fundamental tersebut adalah kejujuran, rasa keadilan, dan rasa tanggung jawab.

Adapun rekomendasi yang penulis harapkan dapat segera terlaksana setelah adanya Pendidikan anti korupsi di Perguruan Tinggi, yaitu

1. Mengupayakan segera integrasi pendidikan antikorupsi pada seluruh lembaga pendidikan, baik lembaga formal maupun non formal.

2. Melaksanakan monitoring dan evaluasi terhadap Perguruan Tinggi yang telah mengintegrasikan pendidikan antikorupsi.

3. Memberikan pembekalan bagi para Dosen berupa pendidikan maupun pelatihan khusus tentang berbagai hal yang terkait dengan korupsi, baik mengenai perancangan program, pembuatan kisi-kisi, penentuan atau pemilihan metode pembelajaran dan sumber belajar, bahkan sampai pada tahap evaluasinya.

\section{REFERENSI}

Buku dan Jurnal:

1. Achmad Ali, 2009. Menguak Teori Hukum dan Teori Peradilan Vol 1. Kencana:Jakarta.

2. Friedman, Howard S. dan Mariam W. Schustrack. 2006. Kepribadian: Teori Klasik dan Riset Modern. Jakarta: Erlangga.

3. Djabbar, Faisal. 2009. Tentang Kurikulum Antikorupsi.

4. Balitbang-Puskur, Kurikulum Berbasis Kompetensi Mata Pelajaran Budi Pekerti untuk Sekolah Menengah Atas, Buram ke-6 Juli 2001, Jakarta : Depdiknas, 2001.

5. Drehel, Axel and Christos Kotsogiannis, Corruption Around the World: Evidence from a Structural Mode. 2004

6. Soedijarto, 2008, Pendidikan, Kemanusiaan, dan Peradaban dalam Landasan dan Arah Pendidikan Nasional Kita. Kompas;Jakarta

7. Sajipto Rahadjo, 2009. Hukum dan Perilaku. Kompas:Jakarta

Bahan Internet:

1. http://soloraya.net/blog/2010/01/11/korupsi-dan-pengertiannya/

2. http://www.riaumandiri.net

3. http://niamw.wordpress.com

4. http://smk3ae.wordpress.com/2009/02/02/tentang-kurikulum-antikorupsi$2 /$

5. http://acch.kpk.go.id/pendidikan-antikorupsi-untuk-perguruan-tinggi

6. http://wgsuacana.files.wordpress.com/2014/01/2012-pendidikan-antikorupsi.pdf 
7. http://elokrohmawati.blogspot.com/2014/04/pendidikan-anti-korupsiuntuk-perguruan.html

8. http://ristydwi-risty.blogspot.com/2012/01/pendidikan-dan-kesadaranhukum.html

9. http://jdih.jatimprov.go.id/kabnganjuk/index.php?option=com_content\&t ask=view\&id=114\&Itemid=63 